\title{
ANALISIS YURIDIS TERHADAP KEPUTUSAN CIRCULAR RESOLUTION RAPAT UMUM PEMEGANG SAHAM DALAM PEMBERHENTIAN DIREKSI
}

\author{
Okky Maharani Wibisono \\ Fakultas Hukum, Universitas Airlangga \\ e-mail: okkmaharaniw@gmail.com
}

\begin{abstract}
ABSTRAK
Salah satu hal penting yang harus dilakukan Perseroan Terbatas (PT) demi kepentingannya sesuai dengan maksud dan tujuan PT adalah pengambilan keputusan. Para pemegang saham dapat mengambil keputusan di luar Rapat Umum Pemegang Saham (RUPS) yang diatur dalam Pasal 91 Undang-Undang Nomor 40 Tahun 2007 tentang Perseroan Terbatas dengan syarat semua pemegang saham menyetujui keputusan secara tertulis, yang dikenal dengan istilah circular resolution. Tidak ada pembatasan mengenai hal-hal apa saja yang dapat dibahas melalui circular resolution, jadi seluruh hal yang dapat diputuskan dalam RUPS, dapat juga dapat diputuskan melalui circular resolution. Dalam penelitian ini akan dibahas mengenai circular resolution dengan agenda pemberhentian direksi. Direksi yang diberhentikan melalui circular resolution diberitahukan terlebih dahulu tentang rencana pemberhentiannya dan diberikan kesempatan untuk melakukan pembelaan secara tertulis. Namun dikarenakan tidak adanya aturan mengenai jangka waktu pelaksanaannya, maka timbul berbagai kendala termasuk dalam pemenuhan hak direksi untuk diberikan kesempatan melakukan pembelaan. Penelitian ini menggunakan pendekatan perundang-undangan, pendekatan konseptual, dan pendekatan kasus. Hasil penelitian menunjukkan bahwa pemberhentian direksi melalui circular resolution yang dilakukan tanpa pemberitahuan dan pemberian jangka waktu yang patut untuk melakukan pembelaan adalah tidak sah karena melanggar asas kepatutan dan tidak sesuai dengan ketentuan yang diatur pada Pasal 105 ayat (3) Undang-Undang Nomor 40 Tahun 2007 tentang Perseroan Terbatas.
\end{abstract}

Kata Kunci: Perseroan Terbatas; Rapat Umum Pemegang Saham; circular resolution; pemberhentian direksi

\begin{abstract}
One of the important things that a limited company should do for its sake based on the intent and purpose of limited company is decision making. The shareholders can take decisions outside the Annual General Meeting (AGM) which is regulated in Article 91 of Law Number 40 Year 2007 concerning Liability Company provided all the shareholders approved the decision in writing, which is known as circular resolution. There is no restriction on any matters that can be decided through a circular resolution, so the whole thing can be decided in the AGM, can also be decided by circular resolution. In this study will be discussed about the circular resolution with the agenda of dismissal of directors. Directors who are dismissed through the circular resolution shall be notified in advance of their dismissal plans and shall be given the opportunity to conduct written defense. However, due to the absence of rules on the duration of implementation, there are various obstacles including in the fulfillment of the right of directors to be given an opportunity to defend. This study used a statute approach, a case study, and a conceptual approach. The results showed that the dismissal of directors through a circular resolution which may be unannounced and delivery timeframe appropriate to undertake the defense was invalid because it violates the principle of propriety/reasonableness and not accordance with the provisions set in Article 105 paragraph (3) of Law Number 40 Year 2007 concerning Liability Company.
\end{abstract}

Keywords: limited liability company; general meeting; circular resolution; dismissal of directors 


\section{PENDAHULUAN}

Perseroan Terbatas (selanjutnya disebut PT) adalah persekutuan yang berbentuk badan hukum, di mana badan hukum ini disebut dengan "perseroan". Istilah perseroan pada perseroan terbatas, menunjuk pada cara penentuan modal pada badan hukum itu, yang terdiri dari sero-sero atau saham-saham, sedangkan istilah terbatas menunjuk pada batas tanggung jawab para persero atau pemegang saham, yaitu hanya terbatas pada jumlah nilai nominal dari semua saham-saham yang dimiliki. ${ }^{1}$ Oleh karena modalnya terdiri atas saham-saham yang diperjualbelikan itulah, perubahan kepemilikan sebuah PT dapat dilakukan tanpa membubarkan perusahaan. $^{2}$

Salah satu hal penting yang harus dilakukan oleh suatu PT demi kepentingannya sesuai dengan maksud dan tujuan PT adalah pengambilan keputusan. Masing-masing organ pada PT dalam suatu keadaan dapat membuat keputusan yang dapat dianggap sebagai keputusan-keputusan perusahaan.

Selain melalui Rapat Umum Pemegang Saham (selanjutnya disebut RUPS), oleh Pasal 91 Undang-Undang Nomor 40 Tahun 2007 tentang Perseroan Terbatas (selanjutnya disebut UUPT) juga dimungkinkan kepada pemegang saham untuk mengambil keputusan di luar RUPS, yang dalam praktik disebut dengan circular resolution atau keputusan para pemegang saham secara sirkuler. Para pemegang saham tidak mengadakan RUPS, tetapi mengambil keputusan dengan menandatangani dokumen keputusan pemegang saham yang diedarkan dari satu pemegang saham ke pemegang saham lainnya. Keputusan ini sah dan berkekuatan selayaknya keputusan RUPS hanya jika disetujui dan ditandatangani oleh seluruh pemegang saham yang mempunyai hak suara. ${ }^{3}$

Hasil dari circular resolution sering disebut dengan keputusan sirkuler. Keputusan sirkuler merupakan akta bawah tangan yang selanjutnya dituangkan ke dalam akta otentik. Pada UUPT tidak ada pembatasan mengenai hal-hal apa saja yang

${ }^{1}$ C.S.T. Kansil. (1996). Pokok-Pokok Hukum Perseroan Terbatas. Jakarta: Pustaka Sinar Harapan, h. 31.

2 Orinton Purba. (2011). "Perseroan Terbatas Dimata Hukum”. Jakarta: Sinar Grafika, h. 12.

${ }^{3}$ Hasbullah F. Sjawie. (2013). Direksi Perseroan Terbatas serta Pertanggungjawaban Pidana Korporasi. Bandung: Citra Aditya Bakti, h. 92. dapat dibahas melalui circular resolution, sehingga menimbulkan pemahaman dan penafsiran yang berbeda-beda oleh para pelakunya. Berdasarkan Pasal 91 UUPT, bahwa pemegang saham dapat juga mengambil keputusan yang mengikat di luar RUPS dengan syarat semua pemegang saham dengan hak suara menyetujui secara tertulis dengan menandatangani usul yang bersangkutan.

Pengaturan mengenai circular resolution dalam UUPT diharapkan dapat menjadi sebuah terobosan untuk memudahkan para pemegang saham karena kesulitan untuk berkumpulnya para pemegang saham dalam satu waktu dan tempat tertentu. Harapan keefisiensian dengan diaturnya mengenai pelaksanaan circular resolution ini, yaitu agar halhal yang membutuhkan persetujuan para pemegang saham terkait dengan kegiatan atau kebutuhan perseroan yang mendesak dapat segera diatasi dan tidak terjadi hambatan bagi perseroan dalam melakukan kegiatan operasional perusahaannya.

Manakala pengambilan keputusan tersebut dilakukan untuk memberhentikan anggota direksi sebagaimana diatur pada Pasal 105 ayat (3) UUPT, maka terdapat 2 (dua) poin penting dalam pemberhentian direksi melalui circular resolution. Pertama, anggota direksi yang bersangkutan diberi tahu terlebih dahulu tentang rencana pemberhentian tersebut. Kedua, anggota direksi yang bersangkutan diberikan kesempatan untuk membela diri sebelum diambil keputusan pemberhentian.

Namun selanjutnya berdasarkan Pasal 115 ayat (4), apabila yang besangkutan tidak berkeberatan atas pemberhentian tersebut maka kesempatan untuk pembelaan diri tidak diperlukan.

Berkaitan dengan hal tersebut di atas, penulis akan membahas contoh kasus konkrit pada suatu PT (yang selanjutnya akan disebut PT. X). Kasus tersebut berdasarkan adanya gugatan oleh mantan Direktur PT. X yang menyatakan bahwa circular resolution atas pemberhentian jabatannya tidak sesuai dengan prosedur karena merasa tidak menerima surat pemberitahuan rencana pemberhentian jabatannya.

Pemberitahuan pemberhentian dikirimkan kepada mantan Direktur PT. X melalui e-mail yang dikirim pada tanggal 16 Maret 2016 pukul 09.00 WIB. Setelah pemberhentian itu dikirimkan segera kemudian pada pukul 15.00 WIB pada hari itu juga 
keputusan circular resolution yang sudah disetujui semua pemegang saham tersebut dituangkan menjadi akta PKR (selanjutnya disebut Pernyataan Keputusan Rapat) oleh notaris yang kemudian dilakukan pemberitahuan perubahan data perseroan kepada Kementrian Hukum dan Hak Asasi Manusia. Atas perbuatan yang dirasa merugikan tersebut mantan Direktur PT. X kemudian mengajukan gugatan perdata yang menuntut: 1 . Keputusan circular resolution tersebut tidak sah/cacat hukum/cacat prosedur; 2. Meminta untuk diadakan RUPS fisik; 3. Meminta agar jabatannya sebagai Direktur Utama dikembalikan.

Berdasarkan beberapa asas dan peraturan hukum yang ada, penulis akan menganalisis keabsahan pemberhentian direksi melalui beberapa kondisi pemberhentian Direksi PT melalui circular resolution. Pertama, dilakukan tanpa pemberitahuan rencana pemberhentian kepada direksi yang bersangkutan. Kedua, dilakukan pemberitahuan rencana pemberhentian direksi namun pemberian kesempatan pembelaan diberikan dengan tidak patut.

UUPT tidak mengatur mekanisme maupun bentuk pemberitahuan rencana pemberhentian, maka mengenai pemberitahuan tersebut bisa dilakukan dengan surat-menyurat ataupun dengan media lain seperti surat elektronik/electronic mail (e-mail). Bentuk penyampaian pemberitahuan rencana pemberhentian maupun jawaban penyampaian pembelaan direksi yang dilakukan melalui surat elektronik/electronic mail (e-mail), merupakan salah satu bentuk pemanfaatan teknologi media elektronik yang diatur dalam Undang-Undang Nomor 19 Tahun 2016 tentang Perubahan atas Undang-Undang Nomor 11 Tahun 2008 tentang Informasi dan Transaksi Elektronik (selanjutnya disebut UU ITE).

\section{PERUMUSAN MASALAH}

Rumusan masalah dari penelitian ini antara lain adalah bagaimana keabsahan pemberhentian direksi melalui circular resolution serta pemberitahuan rencana pemberhentian dan penyampaian pembelaan direksi dapat disampaikan melalui surat elektronik/ electronic mail (e-mail).

\section{METODE PENELITIAN}

Metode yang digunakan dalam penelitian ini adalah penelitian hukum normatif dengan menggunakan pendekatan perundang-undangan (statute approach), pendekatan konseptual (conceptual approach), serta pendekatan kasus (case study).

Pendekatan perundang-undangan (statute approach) dilakukan dengan menelaah semua undang-undang dan regulasi yang bersangkut paut dengan isu hukum yang sedang ditangani. Peter Mahmud mengatakan, bahwa manfaat penggunaan pendekatan perundang-undangan (statute approach) adalah untuk mencari ratio legis dan dasar ontologis suatu undang-undang, maka akan mampu menangkap kandungan filosofis yang ada di belakang undangundang itu. ${ }^{4}$

Pendekatan konseptual (conceptual approach). Pendekatan konseptual beranjak dari pandanganpandangan dan doktrin-doktrin yang berkembang dalam ilmu hukum. Peneliti akan menemukan ideide yang melahirkan pengertian-pengertian hukum, konsep-konsep hukum, dan asas-asas hukum yang relevan dengan isu hukum yang dihadapi. ${ }^{5}$

Pendekatan kasus (case study) merupakan suatu studi terhadap kasus tertentu dari berbagai aspek hukum. ${ }^{6}$ Penulisan ini didasarkan pada kasus tentang pemberhentian Direksi PT. X melalui circular resolution yang akan dianalisis melalui berbagai peraturan perundang-undangan yang berlaku dan juga berbagai asas hukum.

\section{PEMBAHASAN}

\section{Keabsahan Pemberhentian Direksi Melalui Circular Resolution}

\section{Mekanisme atau prosedur pelaksanaan} circular resolution

Pada umumnya permintaan diselenggarakannya pengambilan suatu keputusan perusahaan dalam RUPS diajukan oleh organ Pemegang Saham atau Dewan Komisaris yang kemudian ditindaklanjuti oleh Direksi. Berdasarkan ketentuan pada Pasal 91 UUPT, maka cukup jelas diketahui bahwa keputusan sirkuler diambil oleh pemegang saham dengan cara mengedarkan usulan kepada para pemegang saham. Seorang Direksi bertindak mewakili pemegang

\footnotetext{
${ }^{4}$ Peter Mahmud Marzuki. (2010). Penelitian Hukum. Jakarta: Kencana Prenada Media Group, h. 96.

5 ibid., h. 137.

${ }^{6}$ ibid., h. 94.
} 
saham berdasarkan penunjukan dan kesepakatan yang tertuang dalam surat kuasa.

Praktik yang dilakukan oleh para pemegang saham yang memiliki hak suara yaitu, pemegang saham melakukan komunikasi perihal hal-hal apa saja yang akan diputuskan dalam keputusan sirkuler. Perseroan mengirimkan keputusan pemegang saham yang telah disepakati para pemegang saham tersebut dari pemegang saham ke pemegang saham yang lain untuk ditandatangani. Pemegang saham yang terakhir menandatanganinya dan mengirimkan kembali kepada perseroan untuk disahkan melalui notaris dengan dibuatkan akta otentik. Sebelum penuangan persetujuan dalam keputusan sirkuler, teknik komunikasi pengiriman maksud dari keputusan yang direncanakan dapat dilakukan melalui pengiriman pos/fax/e-mail, dan media elektronik lainnya yang diatur dalam UU ITE.

Berikut konsep secara rinci terkait langkah pelaksanaan circular resolution:

\section{Bagan Langkah Pelaksanaan Circular Resolution}

1. pemegang saham memberikan kuasa kepada direksi untuk melaksakanan circular resolution

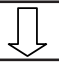

2. usulan keputusan sirkuler dikomunikasikan (telepon/fax/email) kepada semua pemegang saham

3. dilakukan pertimbangan/pengecekan/revisi
$\begin{aligned} & \text { 4. keputusan sirkuler diedarkan kepada seluruh pemegang } \\ & \text { saham }\end{aligned}$

penandatanganan keputusan sirkuler oleh semua pemegang
saham

6. keputusan sirkuler dituangkan menjadi akta otentik berupa akta PKR oleh Notaris

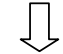

7. disetujui oleh Menteri, didaftarkan, dan diumumkan (Pasal 21 ayat (1) UUPT)

atau

8. diberitahukan pada Menteri (Pasal 21 ayat (3) UUPT)

\section{Penjelasan :}

1. Pemegang saham memberikan kuasa kepada direksi untuk melaksanakan RUPS circular resolution;

2. Direksi sebagai pelaksana yang ditunjuk mengumpulkan usulan-usulan dari pemegang saham mengenai apa saja yang dikehendaki oleh para pemegang saham di dalam circular circulation, dan dikomunikasikan antara pemegang saham lainnya;

3. Direksi melakukan konfirmasi ulang kepada para pemegang saham terkait hal-hal yang dikehendaki;

4. Direksi meminta persetujuan tertulis pemegang saham, dilakukan dengan cara mengedarkan keputusan sirkuler;

5. Circular circulation ditandatangani oleh semua pemegang saham;

6. Direksi menghadap pada notaris dengan membawa keputusan sirkuler yang telah ditandatangani oleh semua pemegang saham;

7. Perubahan anggaran dasar tertentu harus mendapat persetujuan Menteri;

8. Perubahan anggaran dasar selain dimaksud pada Pasal 21 ayat (2) UUPT cukup diberitahukan kepada Menteri.

\section{Mekanisme atau prosedur pemberhentian direksi melalui circular resolution}

Pemberhentian direksi melalui circular resolution diatur pada Pasal 105 ayat (3) UUPT sebagai berikut: Dalam hal keputusan untuk memberhentikan anggota direksi sebagaimana dimaksud pada ayat (2) dilakukan dengan keputusan di luar RUPS sesuai dengan ketentuan sebagaimana dimaksud dalam Pasal 91, anggota direksi yang bersangkutan diberi tahu terlebih dahulu tentang rencana pemberhentian dan diberikan kesempatan untuk membela diri sebelum diambil keputusan pemberhentian.

Terdapat 2 (dua) poin penting dalam pemberhentian direksi melalui circular resolution sebagaimana diatur dalam pasal tersebut di atas. Pertama, anggota direksi yang bersangkutan diberi tahu terlebih dahulu tentang rencana pemberhentian tersebut. Kedua, anggota direksi yang bersangkutan diberikan kesempatan untuk membela diri sebelum diambil keputusan pemberhentian. Namun apabila Direksi yang bersangkutan tidak berkeberatan atas pemberhentian jabatannya maka, berdasarkan Pasal 115 ayat (4) kesempatan untuk pembelaan diri tersebut tidak diperlukan.

Berdasarkan dua poin penting tersebut di atas, maka penulis mencoba membuat konsep secara rinci terkait pelaksanaan pemberhentian direksi melalui circular resolution sebagai berikut: Pemberhentian direksi bukan merupakan salah satu perubahan anggaran dasar tertentu sesuai Pasal 21 ayat (2) UUPT, maka perubahan anggaran dasar mengenai penggantian direksi hanya perlu atau cukup diberitahukan kepada Menteri. Pemberitahuan tersebut merupakan perubahan data perseroan yang tata caranya diatur pada Peraturan Menteri 


\section{Bagan Langkah Pelaksanaan Pemberhentian Direksi Melalui Circular Resolution}

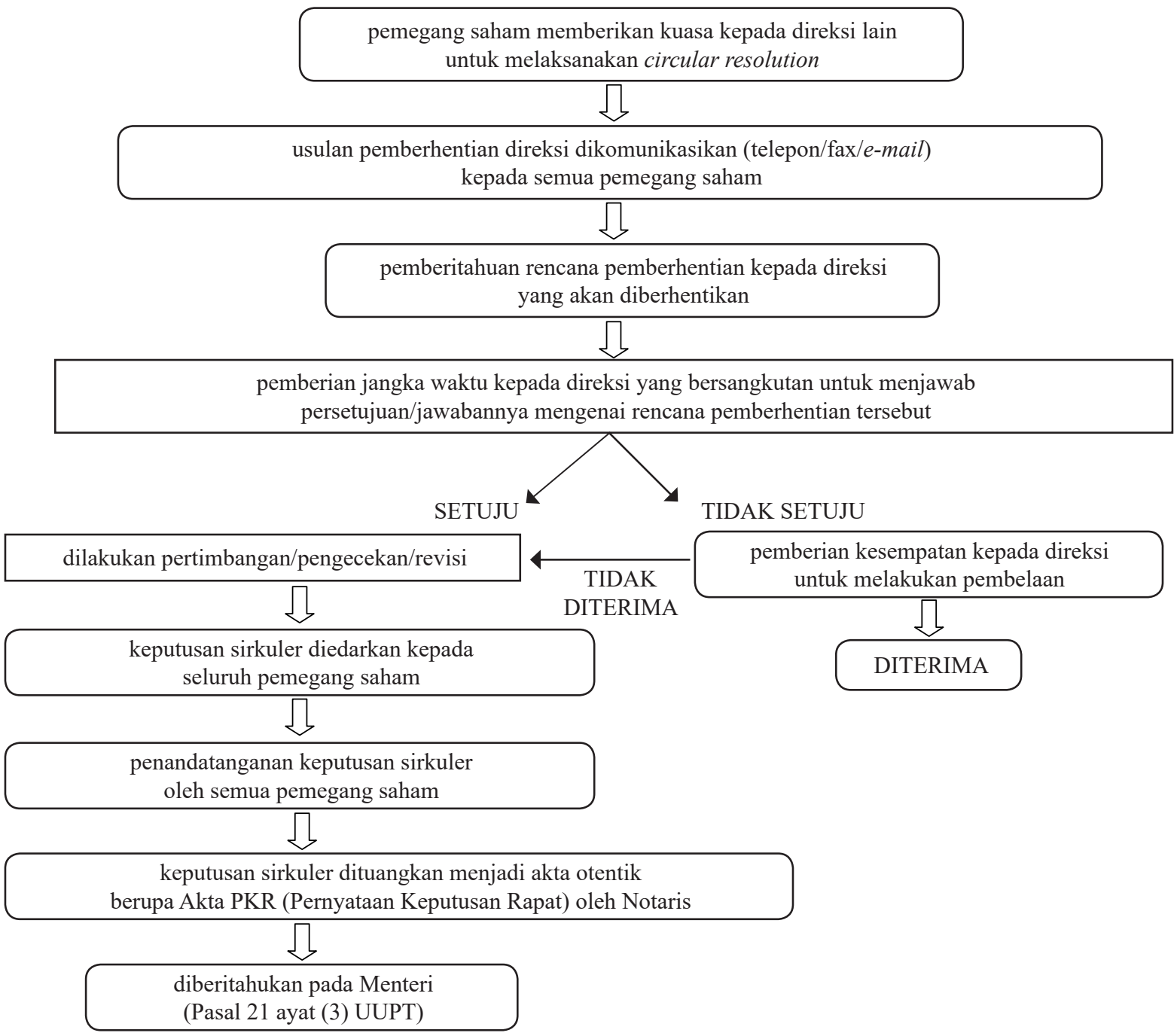

Hukum dan Hak Asasi Manusia Nomor 4 Tahun 2014 dan Nomor 1 Tahun 2016 tentang Tata Cara Pengajuan Permohonan Pengesahan Badan Hukum dan Persetujuan Perubahan Anggaran Dasar serta Penyampaian Pemberitahuan Perubahan Anggaran Dasar dan Perubahan Data Perseroan.

Keabsahan Pemberhentian Direksi Melalui Circular Resolution Yang Dilakukan Tanpa Pemberitahuan Rencana Pemberhentian

Mengenai keabsahan pemberhentian direksi melalui circular resolution, berikut konsep secara rinci terkait pelaksanaannya dilihat dari ada tidaknya pemberitahuan maupun pembelaan yang dilakukan oleh direksi yang hendak diberhentikan:

\section{Keterangan:}

1. Pemberitahuan mengenai rencana pemberhentian kepada direksi yang bersangkutan;

2. Apabila rencana pemberhentian tersebut tidak dilakukan, maka pemberhentian direksi melalui circular resolution tersebut akan menjadi tidak sah;

3. Setelah pemberitahuan rencana pemberhentian diterima, direksi yang bersangkutan menjawab pemberitahuan tersebut;

4. Apabila direksi tidak keberatan mengenai rencana pemberhentiannya, maka pemberhentian direksi melalui circular resolution tersebut dapat terus dilaksanakan/dapat dinyatakan sah;

5. Apabila direksi berkeberatan atas rencana pemberhentian tersebut, maka direksi berhak melakukan pembelaan diri secara tertulis;

6. Apabila direksi tidak diberikan kesempatan untuk melakukan pembelaan diri, maka pemberhentian direksi melalui circular resolution tersebut tidak sah;

7. Direksi melakukan pembelaan diri secara tertulis setelah menjawab/membalas pemberitahuan tersebut. 
Bagan Pemberitahuan Rencana Pemberhentian Direksi Melalui Circular Resolution

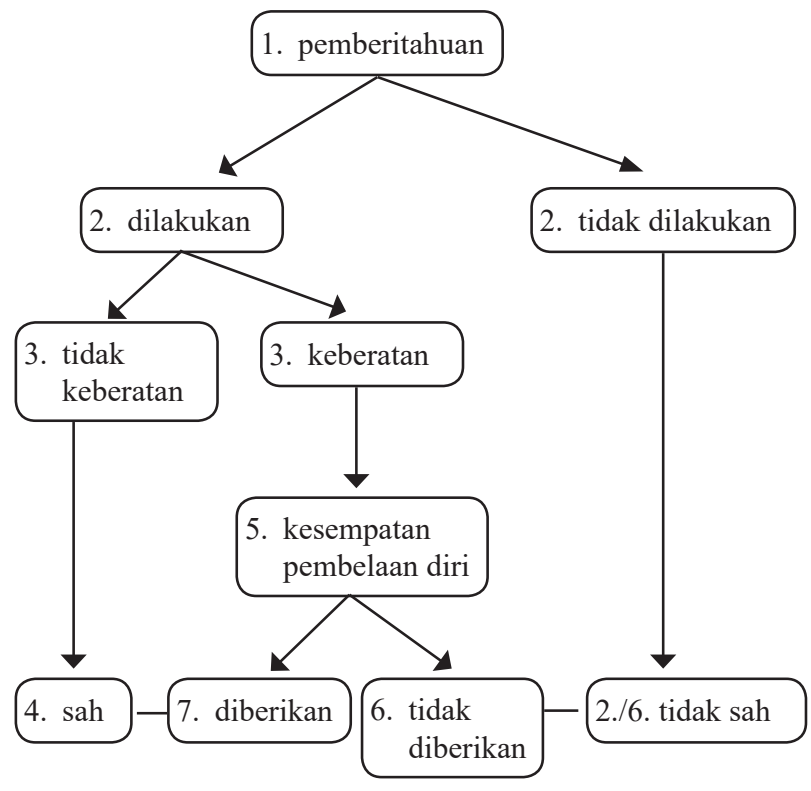

Jadi, pemberhentian direksi melalui circular resolution menjadi sah apabila: Pertama, hasil dari circular resolution tersebut melampirkan surat jawaban direksi mengenai persetujuannya terhadap pemberhentian jabatannya (apabila direksi yang bersangkutan tidak keberatan atas pemberhentiannya). Kedua, Hasil dari circular resolution tersebut melampirkan surat jawaban direksi mengenai persetujuannya terhadap pemberhentian jabatannya, dan ketiga, pembelaan tertulis oleh direksi yang bersangkutan (apabila direksi yang bersangkutan keberatan atas pemberhentiannya).

Surat jawaban beserta pembelaan direksi tersebut nantinya dilampirkan pada keputusan sirkuler untuk ditandatangani semua pemegang saham sebagai kelengkapan dokumen untuk dituangkan dalam PKR yang dibuat oleh Notaris.

Maka dapat disimpulkan bahwa pemberhentian direksi melalui circular resolution yang dilakukan tanpa pemberitahuan terlebih dahulu tentang rencana pemberhentian tersebut, adalah tidak sah karena tidak sesuai dengan ketentuan atau aturan yang diatur pada Pasal 105 ayat (3) UUPT.

Keabsahan Pemberhentian Direksi Melalui Circular Resolution yang Dilakukan Pemberhentian Rencana Pemberhentian, Namun Pemberian Kesempatan Pembelaan Tidak Patut

Anggota direksi dapat diberhentikan sewaktuwaktu melalui RUPS atau keputusan di luar RUPS (circular resolution). Pemberhentian direksi pada Pasal 105 UUPT (ayat 1) yaitu snggota direksi dapat diberhentikan sewaktu-waktu berdasarkan keputusan RUPS dengan menyebutkan alasannya. Pasal 105 ayat (2), Keputusan untuk memberhentikan anggota direksi sebagaimana dimaksud pada ayat (1) diambil setelah yang bersangkutan diberi kesempatan untuk membela diri dalam RUPS.

Dalam prakteknya, alasan pemberhentian Direksi PT. X didasarkan atas laporan saldo defisit keuangan PT. X dan penurunan likuiditas karena manajemen piutang yang tidak berjalan dengan baik, maka alasan tersebut dapat dipertimbangkan sebagai alasan bahwa Direksi PT. X telah melakukan tindakan yang merugikan perseroan sebagaimana diatur dalam penjelasan Pasal 105 ayat (1) UUPT. ${ }^{7}$

Pemberhentian direksi dilakukan dengan menyebutkan alasannya setelah yang bersangkutan diberi kesempatan untuk membela diri dalam RUPS. Sama halnya dengan pengambilan keputusan pemberhentian direksi melalui circular resolution, pemberhentian juga harus dilaksanakan setelah pemberian kesempatan untuk membela diri kepada direksi yang bersangkutan.

Asas kepatutan diatur dalam UUPT yang dijelaskan dalam penjelasan Pasal 4 mengenai kewajiban perseroan bahwa dalam menjalankan perseroan, perseroan berkewajiban mentaati asasasas sebagai berikut:

1. Asas itikad baik;

2. Asas kepantasan;

3. Asas kepatutan;

4. Prinsip tata kelola perseroan yang baik (good corporate governance).

Asas itikad baik dalam Pasal 1338 ayat (3) BW disebutkan bahwa, perjanjian harus dilaksanakan dengan itikad baik. Menurut Hoge Raad dalam putusannya tanggal 9 Februari 1923 memberikan rumusan bahwa perjanjian harus dilaksanakan "volgens de eisen van redelijkheid enbillijkheid" artinya itikad baik harus dilaksanakan menurut kepatutan dan kepantasan.

Menurut Wiryono Prodjodikoro, asas kepatutan yang harus dicapai dalam melakukan persetujuan terletak pada persoalan yang tidak diduga oleh kedua belah pihak pada saat persetujuan terbentuk,

${ }^{7}$ Surat Eksepsi PT. X terhadap Surat Gugatan Mantan Direktur PT. X. 
yang seringkali menimbulkan bermacam-macam persoalan. ${ }^{8}$

Dalam suatu tata hukum pada hakekatnya tidak diperbolehkan suatu kepentingan seorang dipenuhi seluruhnya, namun kepentingan orang lain didesak atau diabaikan. Seberapa teliti pun suatu peraturan hukum pada umumnya atau suatu peraturan perjanjian pada khususnya yang dibuat, dalam pelaksanaannya selalu terjadi banyak keganjilan, maka dalam melakukan persetujuan kedua belah pihak harus memperhatikan tujuan dari peraturan hukum agar ada keseimbangan dari berbagai kepentingan. ${ }^{9}$

Berdasarkan pendapat tersebut di atas, maka dapat disimpulkan bahwa antara asas itikad baik dan asas kepatutan merupakan dua asas yang mempunyai pengertian yang sangat dekat, bahkan dapat dikatakan bahwa asas kepatutan merupakan wujud nyata dari asas itikad baik dalam pelaksanaan perjanjian.

Konsep persetujuan sebagaimana dikemukakan oleh Wiryono Prodjodikoro di atas, penulis kaitkan dengan konsep persetujuan pada proses pemberitahuan rencana pemberhentian direksi dan jawaban atas ada tidaknya pembelaan terhadap pemberhentian tersebut. Pemberitahuan tersebut terdapat proses persetujuan antara dua pihak.

Proses persetujuan yang diberikan terhadap pemberitahuan rencana pemberhentian melalui $e$-mail kepada Direksi PT. X dilakukan secara tidak patut, karena tidak adanya pemberian kesempatan yang patut kepada Direksi PT. X untuk memberikan jawaban atas ada tidaknya keberatan untuk melakukan pembelaan. Hal tersebut tentu saja melanggar hak salah satu pihak. Pemberhentian direksi melalui circular resolution yang dilakukan dengan pemberitahuan tentang rencana pemberhentian tersebut melalui e-mail, namun tidak adanya pemberian kesempatan yang patut kepada Direksi PT. X untuk memberikan jawaban atas persetujuan atau pembelaannya, adalah tidak sah dan batal demi hukum.

\section{Bentuk Pemberitahuan Rencana Pemberhentian} dan Penyampaian Pembelaan Direksi Melalui Surat Elektronik/Electronic Mail (E-mail)

Oleh karena mekanisme pemberhentian direksi melalui circular resolution tidak dilakukan secara

8 Wiryono Prodjodikoro. (1966). Asas-Asas Hukum Perjanjian. Bandung: Sumur, h. 79.

${ }^{9}$ ibid., h. 81. langsung atau pertemuan secara fisik, maka untuk keefisiensian sesuai dengan tujuan diaturnya circular resolution, mekanisme penyampaian pemberitahuan rencana pemberhentian direksi dilakukan melalui surat-menyurat/fax/surat elektronik (e-mail). UUPT tidak mengatur mekanisme pemberitahuan rencana pemberhentian dan keberatan itu harus seperti apa, maka pembuktian mengenai pemberitahuan maupun keberatan tersebut bisa dilakukan entah dengan suratmenyurat ataupun dengan media lain seperti surat elektronik/electronic mail (e-mail).

Bentuk penyampaian pemberitahuan rencana pemberhentian direksi yang dilakukan PT. X melalui surat elektronik/electronic mail (e-mail) merupakan salah satu bentuk pemanfaatan teknologi transaksi elektronik. Berdasarkan Pasal 1 angka 2 UU ITE, pengertian transaksi elektronik adalah perbuatan hukum yang dilakukan dengan menggunakan komputer, jaringan komputer, dan/atau media elektronik lainnya.

Pasal 5 ayat (1) sampai dengan ayat (4) UU ITE secara tegas menyebutkan bahwa informasi elektronik dan/atau hasil cetaknya merupakan alat bukti yang sah yang merupakan perluasan dari alat bukti yang sesuai dengan hukum acara yang berlaku di Indonesia sesuai dengan ketentuan yang diatur dalam undang-undang. Namun dalam ayat (4) ada pengecualian yang menyebutkan informasi elektronik dan/atau dokumen elektronik tidak berlaku untuk: a. Surat yang menurut undang-undang harus dibuat dalam bentuk tertulis; dan b. Surat beserta dokumennya yang menurut undang-undang harus dibuat dalam bentuk akta notarial atau akta yang dibuat oleh pejabat pembuat akta.

Pemberitahuan rencana pemberhentian yang dikirimkan kepada Direksi PT. X yang bersangkutan dilakukan melalui bentuk e-mail atau media elektronik. Berkaitan dengan hal tersebut, UUPT tidak mengatur mengenai bentuknya. Lahirnya UUPT, melalui Pasal 77 UUPT mengakomodasi kemudahan pengambilan keputusan oleh para pemegang saham yang berada di tempat-tempat berbeda yang bahkan mungkin satu sama lain berada pada beda negara melalui telekonferensi. UUPT menampung perkembangan teknologi informasi dengan diterimanya telekonferensi, video konferensi. Sarana komunikasi yang demikian ini membawa dampak dalam memberikan kemudahan dari sisi 
ekonomis. Bertatap muka tidak dengan konteks bertemu empat mata tetapi bertatap muka dengan media elektronik.

Dengan adanya pengaturan mengenai pengambilan keputusan RUPS melalui telekonferensi dan video konferensi, menunjukkan bahwa telah diterimanya penggunaan media elektronik untuk kemudahan dalam pelaksanaan kepentingan perseroan. Maka pemberitahuan rencana pemberhentian yang dikirimkan kepada Direksi PT. $\mathrm{X}$ melalui bentuk e-mail yang tidak diatur dalam UUPT, dapat dilakukan melalui media elektronik dan dianggap sah sebagai informasi elektronik dan/ atau hasil cetaknya merupakan alat bukti yang sah sebagaimana diatur dalam Pasal 5 ayat (4) UU ITE.

Namun, berdasarkan pada penjelasan Pasal 105 ayat (3) bahwa, pembelaan diri dalam pemberhentian direksi melalui circular resolution dilakukan secara tertulis. Maka, pembelaan diri dalam pemberhentian direksi melalui circular resolution tidak dapat dilakukan melalui media elektronik karena merupakan pengecualian keabsahan pemanfaatan media elektronik/informasi elektronik sebagaimana diatur pada UU ITE.

\section{PENUTUP}

\section{Kesimpulan}

Keabsahan pemberhentian direksi melalui circular resolution ditentukan oleh 2 (dua) poin penting. Pertama, anggota direksi yang bersangkutan diberi tahu terlebih dahulu tentang rencana pemberhentian tersebut. Kedua, anggota direksi yang bersangkutan diberikan kesempatan untuk membela diri sebelum diambil keputusan pemberhentian. Pemberhentian direksi melalui circular resolution yang dilakukan tanpa pemberitahuan dan dengan pemberitahuan namun tidak ada pemberian kesempatan yang patut kepada direksi untuk memberikan jawaban atas persetujuan atau pembelaannya adalah tidak sah dan batal demi hukum karena tidak sesuai dengan ketentuan yang diatur pada Pasal 105 ayat (3) UUPT. Pengaturan mengenai pengambilan keputusan RUPS melalui telekonferensi dan video konferensi, menunjukkan bahwa telah diterimanya penggunaan media elektronik untuk kemudahan dalam pelaksanaan kepentingan perseroan. Pemberitahuan rencana pemberhentian, tidak harus dibuat dalam bentuk tertulis, sehingga dapat dilakukan melalui e-mail/ media elektronik dan dianggap sah sebagai informasi elektronik sebagaimana diatur dalam Pasal 5 ayat (4) UU ITE. Terhadap keberatan atas pemberhentian tersebut, pembelaan diri harus dibuat dalam bentuk tertulis sebagaimana diatur dalam penjelasan Pasal 105 ayat (3) sehingga tidak dapat dilakukan melalui e-mail atau media elektronik lainnya.

\section{Rekomendasi}

Selain syarat yang harus terpenuhi dalam pengambilan keputusan melalui circular resolution bahwa semua pemegang saham harus menyetujui secara bulat tanpa terkecuali, direksi yang bersangkutan harus diberi tahu terlebih dahulu mengenai rencana pemberhentian dan diberikan kesempatan melakukan pembelaan. Berkaitan dengan hal tersebut, dalam pelaksanaannya circular resolution harus tetap memperhatikan beberapa asas hukum khususnya bagaimana asas kepatutan dapat diterapkan dengan baik agar hak semua pihak terpenuhi.

\section{DAFTAR PUSTAKA}

\section{Peraturan Perundangan-undangan:}

Undang-Undang Nomor 1 Tahun 1995 tentang Perseroan Terbatas.

Undang-Undang Nomor 8 Tahun 1997 tentang Dokumen Perusahaan.

Undang-Undang Nomor 30 Tahun 2004 tentang Jabatan Notaris.

Undang-Undang Nomor 40 Tahun 2007 tentang Perseroan Terbatas.

Undang-Undang Nomor 19 Tahun 2016 tentang Perubahan atas Undang-Undang Nomor 11 Tahun 2008 tentang Informasi dan Transaksi Elektronik.

\section{Buku:}

C.S.T. Kansil. (1996). Pokok-Pokok Hukum Perseroan Terbatas. Jakarta: Pustaka Sinar Harapan.

Hasbullah F. Sjawie. (2013). Direksi Perseroan Terbatas serta Pertanggungjawaban Pidana Korporasi. Bandung: Citra Aditya Bakti.

Orinton Purba. (2011). Perseroan Terbatas Dimata Hukum. Jakarta: Sinar Grafika. 
Peter Mahmud Marzuki. (2010). Penelitian Hukum. Jakarta: Kencana Prenada Media Group.

Wiryono Prodjodikoro. (1966). Asas-Asas Hukum Perjanjian. Bandung: Sumur.

\section{Sumber Lain:}

Surat Eksepsi PT. X terhadap Surat Gugatan Mantan Direktur PT. X. 